\title{
Analysis of The Effect of Social Media Advertising and Website or Mobile Apps on Flash Sale Performance: Empirical Study in E-Commerce Indonesia
}

\author{
Sheila Lestari ${ }^{1}$, Yosef Budi Susanto ${ }^{2}$, So Yohanes Jimmy ${ }^{3}$ \\ \{ sheila.lestari@student.umn.ac.id ${ }^{1}$, bsusanto@umn.ac.id ${ }^{2}$, yoh.jimmy@gmail.com ${ }^{3}$ \}
}

Magister Management Technology, Multimedia Nusantara University, Indonesia ${ }^{1,2,3}$

\begin{abstract}
Many flash sales failed even though the promos offered are quite attractive. It could cause by a lack of flash sale information on social media, problems with the website / mobile apps system, and so on. The objective of this study is to analyze the factors that influence purchase intention in flash sale. The novelty of this paper are little empirical research discuss about flash sale and the direct effect ease of use website towards promotion attractiveness. This study is using PLS-SEM with SmartPLS. We collected 73 respondents who are live in Indonesia, actively Instagram users, actively shop online, and users of the TE website. In this study, It can be concluded that almost all hypothesis is accepted. These results contribute to our understanding of flash sale in e-commerce and provide empirical evidence for the importance using social media advertising in omnichannel, cloud computing, artificial intelligence (chatbot), and personalization ads.
\end{abstract}

Keywords: Flash sale, social media advertising, e-commerce, ease of use website, purchase intention

\section{Introduction}

Flash sales are common programs that currently often found and used by various ecommerce platforms in offering products or services. In Indonesia, flash sales often found at Shopee, Tokopedia, Blibli.com, Lazada, Zalora, Bukalapak, JD.ID, and various online shop websites. Flash sales offer discounts on various attractive products with limited time and limited stock. It's not an easy thing to run a flash sale project. There are many things that must be considered in a flash sale such as the flash sale process on social media, a stable system platform or website, and so on. Many flash sales fail even though the promos offered are quite attractive. This has happened in large marketplace like Tokopedia in 2018 [1]. The occurrence of this decline made us interested to know what factors caused failure in flash sales.

The purpose of this study is to identify the factors that influence purchase intention in flash sales. We propose social media advertising [2] and ease of use website [3] as the main determinants. We also employ awareness of flash sale and promo attractiveness as mediators. We argue that the intention of social media advertising (to spread the promo information) and the ease use of website (to spread the promo and transaction media) independently or collaboratively will increase awareness and attractiveness of the flash sale. Finally, high awareness and attractiveness predicted to be positively influence the purchase intention. In other word, we are interested to answer a research question: "how social media advertising and ease of use of website increase purchase intention". 


\section{Literature Review}

\section{Social Media Advertising}

We offer the factors that cause flash sale failure. Starting from social media advertising. According to [2], social media advertising is an interaction activity between organizations and consumers that involves communication and exchange offers that have important value by utilizing social media technology, networks, and software. According to [4], social media is an easy-to-use, low-cost platform that offers consumers a direct link to a brand. According to [5], the first rank of the most popular social network worldwide in July 2020 based on the number of active users is Facebook with 2.6 billion. The sixth place is Instagram with over 1 billion active users. With social media, companies can provide updated promos information very quickly. Social media advertising related to the intensity of a company in informing its promotions on social media. According to [6], social media advertising is influenced by various factors, namely habit, perceived relevance, and interactivity. Summarized from [7], the definition of habit for this study refers to how often the company informs the promos / flash sales. Regarding social media advertising, [8] defines that perceived relevance is the extent to which consumers perceive personalized advertising as something related to themselves or how something can play a role in achieving their personal values and goals. [6] said that interactivity is one of several critical aspects that are very important in online platforms and social media. [9] see interactivity as the exchange of information in real time by two parties. In this study, interactivity defined as how active a company is in informing promotions through social media.

Based on previous research results [10] show that as many as 50.4 percent of participants say that if they see a brand or product that they find on social media, they will recognize it. That study concluded that social media advertising has a positive effect on brand awareness. In this study, we uses awareness of flash sales because it is in accordance with the research objectives that the thing to aim for is online sales of flash sale. So, it can be formulated;

H1: Social media advertising has a positive effect on awareness of flash sales.

Social media advertising is a marketing technique that makes consumers interested in buying promotional items. [11] shows that customers tend to make purchases with the seller who offers the lowest price. In other words, consumers are attracted to the promos offered in social media. In the research [12] said that consumers will visit the company's social media only to look for coupons or promos. Therefore, it can be formulated that:

H2: Social media advertising has a positive effect on promotion attractiveness.

\section{Ease of Use Website}

Second thing is ease of use website. According to [3], there is one of the most important factors in the design of a successful e-commerce site, namely ease of use. According to [13], ease of use of a website is defined as how easily customers access the website. According to [14], there are three factors that affect the ease of use of the website, namely: system quality, information quality, and service quality. For this research, we only focused on appearance, technical adequacy, navigation, and delay. In this study, the measurement of information quality seen from the level of accuracy, relevance, adequacy, and ease of understanding. In this study, the measurement of service quality seen from the speed in handling consumer questions and the accuracy in handling consumer questions.

In a study [15], the use of the ctsurgerypatients.org website is very much needed or very important in providing awareness regarding information to educate the public about cardiothoracic surgery and to provide informative tools that can refer cardiac surgery patients. So, It can be concluded that the use of the website has an effect on awareness of information. 
The use of websites that make it easier for consumers (ease of use of website) also has an important role in making consumers aware of flash sale information. Consumers who have easy access to websites, of course they can easily find flash sales. Therefore, it can formulated that: H3: Ease of use of the website has a positive effect on awareness of flash sales.

According to the CIFE (Consumption Impulse Formation Enactment) Model developed by [16], states that it is important for online retailers to provide adequate marketing stimulation on their websites to entice consumers impulsively buy online. From this model shows that the urge is needed to lure consumers to access the website. Attractive promos offered on the website will trigger consumer to shop on the website. So, we can formulated that:

H4: Ease of use of the website has a positive effect on promotion attractiveness.

\section{Awareness of Flash Sale}

The purpose of this study is to identify the factors that influence purchase intention in flash sales. So, the third thing is awareness of flash sale. According to [17], brand awareness refers to the strength of the brand's presence in the minds of consumers. [17] added that brand awareness can be created with experience, progress, promotion, and so on. Social media presents a way to create consumer awareness. Consumers are exposed to advertisements and information created by platforms on social media. According to [18] companies that use social media platforms can promote their brand and create awareness then change this awareness into purchasing behavior. On the other hand, website also can create awareness of flash sale. When consumer visit website, they can see and recognize the promo. In this study, we changed the name brand awareness to awareness of flash sales because the main focus is flash sale.

Based on previous research, [10] concluded that awareness has a positive effect on purchase intention. In that study, as many as 91.2 percent of participants followed the types of clothing and accessories on social media. As many as 46.2 percent of participants made purchases of clothing and accessories products from the social media content that they followed. This shows that the role of social media in building awareness is very important. According to [19], there are other events to increase consumer awareness of the brand, through promotion and sales. Therefore, people who are initially aware of promo information (through social media or websites) can build their awareness of the desire to buy products. So, we can formulate that; H5: Awareness of flash sale has a positive effect on purchase intention.

\section{Promotion Attractiveness}

The fourth is promotion attractiveness. Promotion attractiveness refers to the attractiveness of promotion. Brands tend to have an attractive identity when the brand association matches the consumer's sense of self [20]. Brand attractiveness is likely related to the extent to which customers perceive users of other brands to be similar to themselves; such brands resemble the feeling of who they are, offering the possibility to express themselves and paving the way for them to positively evaluate brands [21]. Promotion attractiveness refers to the attractiveness of promotion. Other researcher such as [22] also consider attractiveness as an emotional response to the desire to be closer to certain buyers.

Based on previous research, [23] concluded that discount promotion has a positive effect on consumer purchase intention. In this research, discount promotion is one way to create attractiveness in promotion. [23] said that the great er the level of promotion attractiveness, the greater the level of purchase intention. [24] investigated the interaction of promotional attractiveness between monetary and non-monetary campaigns. The results show that attractive discount promotions positively affect purchase intention. So that the author can formulate that; H6: Promotion of attractiveness has a positive effect on purchase intention. 


\section{Purchase Intention}

According to [22], purchase intention is the tendency of consumers to buy products in the decision-making process and develop a desire for the product or brand. According to [25], purchase intention refers to three statements: a) the willingness of consumers to consider purchases, b) the intention to make purchases in the future, c) considering repurchases.

\section{Methodology and Data Analysis}

\subsection{Sample and Data Collection}

The data collected from 73 respondents who are live in Indonesia, actively Instagram users, actively shop online, and users of the TE website. TE website is a fashion retail brand website that well known in Indonesia. We distributed 32 measurement items (with a 5-point Likert scale) to them via email (questionnaires are on Google Form). The responses were also sent back via email and Google Form. These respondents are $85 \%$ female and $15 \%$ male. Their age are $70 \%$ 25-30 years old, $29 \%$ below 25 years old, and $1 \%$ above 30 years old. They are mostly live in Jakarta with $33 \%$ and $21 \%$ in Tangerang. Based on profession, all of them are employee. Based on educational background, all of them are bachelor degree. Based on monthly income, $77 \%$ respondents are IDR 5.000.001-IDR 7.000.000, 12\% respondents above IDR 7.000.001, and $11 \%$ respondents are IDR 3.000.001-IDR 5.000.000. Based on monthly expenses, $84 \%$ answer IDR 3.000.001-IDR 5.000.000.

\subsection{Analysis Method}

We use SmartPLS version 3.0 to analyze the data. The software is suitable for testing the formative and reflective variables [26] as well as suitable for the small size data (below 100) [26]. We tested the outer model by measuring Convergent Validity, Discriminant Validity, Composite Reliability, and Average Variance Extracted (AVE) [26]. We then tested the inner model by looking at the value of $\mathrm{R}^{2}$ which is the goodness of fit. All variables categorized as moderate level. Finally, we tested the hypothesis by bootstrapping the sample to 500 respondents. With this doubling, it can show more significant results.

\section{Result \& Discussion}

Table 1 below is the descriptive statistic of data in this research

Table 1. Descriptive Statistic

\begin{tabular}{|c|c|c|c|c|c|c|c|c|}
\hline & Variables & Mean & S.D. & 1 & 2 & 3 & 4 & 5 \\
\hline 1 & $\begin{array}{l}\text { Social Media } \\
\text { Advertising }\end{array}$ & 3.40 & 0.51 & 1 & & & & \\
\hline 2 & Ease of Use Website & 3.51 & 0.42 & $0.269 *$ & 1 & & & \\
\hline 3 & Awareness of Flash Sale & 4.07 & 0.64 & $\begin{array}{l}0.601 * \\
*\end{array}$ & $\begin{array}{l}0.363 * \\
*\end{array}$ & 1 & & \\
\hline 4 & $\begin{array}{l}\text { Promotion } \\
\text { Attractiveness }\end{array}$ & 3.63 & 0.44 & $\begin{array}{l}0.551 * \\
*\end{array}$ & 0.099 & $\begin{array}{l}0.637 * \\
*\end{array}$ & 1 & \\
\hline
\end{tabular}




$\begin{array}{llllllll}5 & \text { Purchase Intention } & 4.02 & 0.86 & \begin{array}{l}0.505^{*} \\ *\end{array} & \begin{array}{l}0.316^{*} \\ *\end{array} & \begin{array}{l}0.780 * \\ *\end{array} & \begin{array}{l}0.679 * \\ *\end{array}\end{array}$

$$
\begin{aligned}
& \mathrm{N}=73 \\
& * * p<.01, \text { two-tailed. } * p<.05, \text { two-tailed. }
\end{aligned}
$$

The lowest mean score on social media advertising is SMA6 "the frequently promotion of flash sale on social media" with 1.51. The highest loading factor on social media advertising is SMA4 "I often get information about TE flash sale on social media" with 0.796 . The lowest mean score on ease of use website is EOU8 "service quality $\rightarrow$ quick response" with 2.14 . The highest loading factor on ease of use website is EOU5 "system quality $\rightarrow$ easy to transaction" with 0.820 , but it has low mean score (only 3.08). The highest loading factor on promotion attractiveness are PA1 "interesting promo" with 0.843 and PA7 "browsing more product" with 0.786 . The composite reliability on each variable are: $0.886 ; 0.851 ; 0.936 ; 0.821 ; 0.978$. The $\mathrm{R}^{2}$ on each variable are: $1 ; 1 ; 0.505 ; 0.375 ; 0.628$.

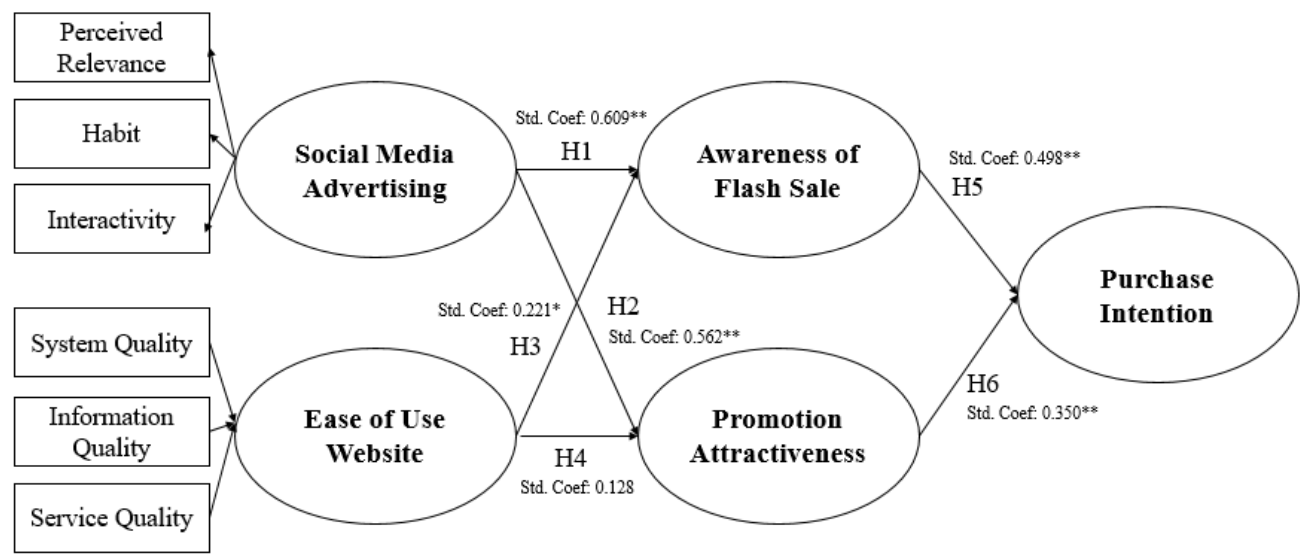

Figure 1. Structural Model

On Figure 1 shown that H1, H2, H3, H5, and H6 have a supporting hypothesis, which means that they have a positive standard coefficient and with a p-value below 0.05 or $5 \%$. Meanwhile, H4 has a non-supporting hypothesis. By analyzing the measurement items, we arrive at the conclusion that customers willing to enter the website mainly to accomplish the transaction after exploring the more attractive promo in the social media. Thus, website itself does not have big influence to increase the attractiveness of promo.

\section{Conclusion, Implications, Limitations, and Suggestions for Further Research}

The cause of the failure of a flash sale program on the TE website is the lack of incessant promos on Instagram, consumers who do not pay attention to flash sale promos on the website, lack of customer service on the website (low response), and lack of website transaction systems (to provide convenience in transactions). The company should pay attention on the lowest mean score and the highest loading factor. To increase purchase intention, the company must be more aggressive in promoting flash sales on Instagram and using other social media (omni-channel such as Facebook, Twitter, and Line). The company also needs to use artificial intelligence 
(chatbot) to increase customer service responsive, reducing errors in the website system (system quality) by using cloud computing, and increase awareness of flash sales, promotion attractiveness, and purchase intention through personalization ads.

You can investigate further how to improve the quality of the website (from system to service) to make it more user friendly and easier to transact (for example via a smartphone that connected to GoPay, OVO, and ShopeePay). Also, based on H4 model and result, you can investigate further how the website can increasing attractiveness (not just transactions).

\section{References}

[1] H. Soeprajitno, “Jangan Main-Main dengan Flash Sale," 2018. [Online]. Available: https://marketeers.com/jangan-main-main-dengan-flash-sale/. [Accessed: 20-Dec2019].

[2] L. S. Tuten, Tracy, Social Media Marketing Strategy. 2018.

[3] K. C. Laudon and C. G. Traver, E-commerce 2016: business. technology. society. 2016.

[4] C. McClure and Y. K. Seock, "The role of involvement: Investigating the effect of brand's social media pages on consumer purchase intention," J. Retail. Consum. Serv., 2020, doi: 10.1016/j.jretconser.2019.101975.

[5] statista.com, "statista.com," J. Clement, 2020. [Online]. Available: https://www.statista.com/statistics/272014/global-social-networks-ranked-by-numberof-users/\#: :text=What is the most popular, 1 billion monthly active accounts. [Accessed: 30-Aug-2020].

[6] A. A. Alalwan, "Investigating the impact of social media advertising features on customer purchase intention," Int. J. Inf. Manage., 2018, doi: 10.1016/j.ijinfomgt.2018.06.001.

[7] V. Venkatesh, J. Y. L. Thong, and X. Xu, "Consumer acceptance and use of information technology: Extending the unified theory of acceptance and use of technology," MIS $Q$. Manag. Inf. Syst., 2012, doi: 10.2307/41410412.

[8] Y. Q. Zhu and J. H. Chang, "The key role of relevance in personalized advertisement: Examining its impact on perceptions of privacy invasion, self-awareness, and continuous use intentions," Comput. Human Behav., 2016, doi: 10.1016/j.chb.2016.08.048.

[9] R. E. Rice and F. Williams, "Theories Old and New: The Study of New Media," in The New Media Communication Research and Technology, 1984.

[10] O. Akkaya, M. Zerenler, and N. Ekmekci, "The Impact of Social Media Toward Brand Awareness and Purchase Intention Through Information Sharing: An Empirical Analysis of Cosmetic Brands," in International Symposium for Production Research (ISPR) 2017: “Transition to Industry 4.0,” 2017.

[11] K. L. Ailawadi, S. A. Neslin, and K. Gedenk, "Pursuing the value-conscious consumer: Store brands versus national brand promotions," J. Mark., vol. 65, no. 1, pp. 71-89, 2001, doi: 10.1509/jmkg.65.1.71.18132.

[12] R. Rishika, A. Kumar, R. Janakiraman, and R. Bezawada, "The effect of customers' social media participation on customer visit frequency and profitability: An empirical investigation," Inf. Syst. Res., 2013, doi: 10.1287/isre.1120.0460.

[13] F. D. Davis, "Perceived usefulness, perceived ease of use, and user acceptance of information technology," MIS Q. Manag. Inf. Syst., 1989, doi: 10.2307/249008.

[14] T. Ahn, S. Ryu, and I. Han, "The impact of Web quality and playfulness on user acceptance of online retailing," Inf. Manag., 2007, doi: 10.1016/j.im.2006.12.008. 
[15] R. G. Cohen et al., "The Disparity Between Public Utilization and Surgeon Awareness of the STS Patient Education Website," Ann. Thorac. Surg., 2020, doi: 10.1016/j.athoracsur.2019.09.074.

[16] U. M. Dholakia, "Temptation and resistance: An integrated model of consumption impulse formation and enactment," Psychol. Mark., 2000, doi: 10.1002/15206793(200011)17:11<955::AID-MAR3>3.0.CO;2-J.

[17] K. Hutter, J. Hautz, S. Dennhardt, and J. Füller, "The impact of user interactions in social media on brand awareness and purchase intention: The case of MINI on Facebook,” J. Prod. Brand Manag., 2013, doi: 10.1108/JPBM-05-2013-0299.

[18] L. M. Davis, "Social Media Marketing: An Hour a Day," Tech. Commun., 2010.

[19] S. Kumar Padhy, R. Sawlikar, P. Mahavidyalaya, and C. Corresponding Author, "The Role of Brand Equity And Brand Awareness on Consumers' Purchase Intention," Int. J. Bus. Manag. Invent. ISSN, 2018.

[20] C. B. Bhattacharya and S. Sen, "Consumer-company identification: A framework for understanding consumers' relationships with companies," Journal of Marketing. 2003, doi: 10.1509/jmkg.67.2.76.18609.

[21] R. Currás-Pérez, E. Bigné-Alcañiz, and A. Alvarado-Herrera, "The role of selfdefinitional principles in consumer identification with a socially responsible company," J. Bus. Ethics, 2009, doi: 10.1007/s10551-008-0016-6.

[22] K. S. Hald, C. Cordón, and T. E. Vollmann, "Towards an understanding of attraction in buyer-supplier relationships," Ind. Mark. Manag., 2009, doi: 10.1016/j.indmarman.2008.04.015.

[23] F. de O. Santini, C. H. Sampaio, M. G. Perin, and V. A. Vieira, "An analysis of the influence of discount sales promotion in consumer buying intent and the moderating effects of attractiveness," Rev. Adm., 2015, doi: 10.5700/rausp1210.

[24] E. Delgado-Ballester and M. Palazon, "Effectiveness of price discounts and premium promotions," Psychol. Mark., 2009, doi: 10.1002/mar.20315.

[25] B. K. P. D. Balakrishnan, M. I. Dahnil, and W. J. Yi, "The Impact of Social Media Marketing Medium toward Purchase Intention and Brand Loyalty among Generation Y," Procedia - Soc. Behav. Sci., 2014, doi: 10.1016/j.sbspro.2014.07.032.

[26] J. F. Hair, M. Sarstedt, L. Hopkins, and V. G. Kuppelwieser, "Partial least squares structural equation modeling (PLS-SEM): An emerging tool in business research," European Business Review. 2014, doi: 10.1108/EBR-10-2013-0128. 